\title{
The Effectiveness of a Training Package Prepared to Teach First Aid Skills to Individuals with Intellectual and Additional Disabilities
}

\author{
Müzeyyen ELDENIZ ÇETIN ${ }^{1}$ \& Burak BOZAK $^{1}$ \\ ${ }^{1}$ Bolu Abant Izzet Baysal University, Bolu, Turkey \\ Correspondence: Müzeyyen ELDENIZ ÇETİN, Faculty of Education, Bolu Abant Izzet Baysal University, Bolu, \\ Turkey.
}

Received: September 28, 2019

Accepted: November 11, 2019

Online Published: February 18, 2020

doi:10.5539/ies.v13n3p27

URL: https://doi.org/10.5539/ies.v13n3p27

\begin{abstract}
This study aimed to evaluate the effectiveness of a training package, which was applied through direct teaching method and included digital storytelling, a first aid manikin and live modeling, in teaching basic first aid skills necessary for cuts, sprains and bee stings to individuals with intellectual and additional disabilities. Three middle school students with multiple developmental disabilities whose ages ranged from 12 to 15 participated in the study. The first aid skills for simple cuts, sprains and bee stings were taught in a small group format. A multiple probe design across behaviors with probe conditions, one of the single-subject designs, was employed in the study. The independent variable of the study was training package and the dependent variables of the study were the participants' level of acquisition of the target skills (Cut, sprain and bee sting). The results of the study revealed that the package was effective in teaching simple first aid skills to the participants, and they maintained those skills for 1, 3 and 4 weeks after the completion of training. The participants were also able to generalize the skills to other first aid tools, settings and practitioners. Social validity findings showed that the participants enjoyed the classes in which digital storytelling was used. Also, they expressed their desire to have them in other courses.
\end{abstract}

Keywords: first aid, digital storytelling, direct teaching method, intellectual disability, individual with intellectual and additional disability, safety skills

\section{Introduction}

Intellectual disability is currently defined as "Intellectual disability is a disability characterized by significant limitations in both intellectual functioning and in adaptive behavior, which covers many everyday social and practical skills. This disability originates before the age of 18" (American Association on Intellectual and Developmental Disability [AAIDD], 2019). Among individuals with intellectual disability, other disabilities related to hearing, vision, orthopedics and health may also exist. This condition is referred to as the coexistence of intellectual and other disabilities, and individuals affected by this condition are defined as individuals with intellectual and additional disability. The main purpose of special education services offered to those individuals is to maximize their participation in social life by developing their independent life skills (Ataman, 2003). In order to take part in social life in a successful and high-quality way, adaptive behaviors are very essential for those individuals (Eripek, 2005). Therefore, safety skills, one of the adaptive skills, must be taught to individuals with intellectual and developmental disabilities; thus, they can become more independent and self-sufficient. This way, they will also learn how to behave in a variety of risky and dangerous situations besides avoiding such situations (Agran, Krupp, Spooner, \& Zakas, 2012; Agran, Spooner, \& Zakas, 2008).

The safety skills are the ones to be used in case of emergencies (Collins, Wolery, \& Gast, 1991; Ergenekon, 2012; Gast, Winterling, Wolery, \& Farmar, 1992; Marchand-Martella, \& Martella, Christensen, Agran, \& Young, 1992). Different dimensions of these skills have been dealt with and classified by researchers working in the field (Bambara et al., 2006; Clees \& Gast, 1994; Dixon et al., 2010; Mechling, 2008; Miltenberger \& Gross, 2011; Jang, Mehta, \& Dixon, 2016; Volkmar \& Wiesner, 2009; Zager \& Shamow, 2005). Some researchers have categorized the safety skills as (a) proactive and (b) reactive, based on their being necessary before or after a dangerous situation (Clees \& Gast, 1994). It is possible to give the hazard warning symbols on dangerous chemicals as an example of proactive safety skills (Bozak \& Eldeniz-Çetin, 2017), while basic first aid skills can be given as an example of reactive safety skills (Gast et al., 1992). From a different perspective, some researchers call the above given examples 'home safety skills' considering the location where they occur (Bambara et al., 2006; Ergenekon, 
2012; Volkmar \& Wiesner, 2009; Zager \& Shamow, 2005). However, similar to Clees and Gast (1994), Mechling's (2008) study based on the above mentioned two concepts and studied reactive safety skills. Similarly, in this study, which has been based on the same categorization, the first aid skills are approached as reactive safety skills considering that such skills might be necessary in any setting.

These skills are vital for not only adults and children with normal development but also individuals with intellectual and other disabilities. Such situations as accidents and injuries can result in death if not intervened immediately and properly, which reveals the importance of first aid (Rızalar \& Öztürk, 2015). Giving correct reactions in situations where first aid is needed is one of the vital social life skills for individuals (Marchand-Martella \& Martella 1990; Spooner, Stem, \& Test, 1989). In addition, the first aid skills enable the ones with intellectual and other disabilities to live more independently (Timko \& Sainato, 1999).

Therefore, they must systematically be taught to individuals in both groups. Research on teaching safety skills to children follows two main approaches, which are passive and active learning approaches. In passive learning approach, a teacher informs a student of security threats, defines correct responses to such threats and models them. On the other hand, active learning approach involves (a) behavioral skills training and (b) in situ training. In the behavioral skills training, the teacher defines a security threat and related safety skills which students later rehearse; then corrective feedback and reinforcement are provided. However, on situ training involves teaching those skills in a real environment or a very similar setting rather than a classroom setting (Miltenberger, Sanches, \& Valbuena, 2015). One of the teaching methods that make it possible to educate individuals with intellectual disability in a more systematic way following both active and passive learning approaches is direct teaching method.

This method is considered to be an effective way of teaching because it allows teachers to plan their lessons in a cautious and flexible manner, and it provides high quality instructional interactions with all students including the disadvantaged ones with low performance (Liem \& Martin, 2013). The direct teaching method, which was developed by Siegfried Engelmann and his colleagues, is supported by a vast body of research conducted throughout many years. In this method, which is a teacher-centered and skill-oriented, skill are taught in a systematic way by dividing them into sub-skills, and face-to-face teaching is done in small groups (Schug, Tarver, \& Western, 2001; Traub, 1999).

In the field literature, there are various studies in which direct teaching method has been used to teach basic skills like reading, writing, language, mathematics, social studies, science and conceptual learning to individuals with intellectual disability (Güzel, 1998, 1999; Dağseven, 2001; Sazak-Pınar \& Merdan, 2016; Vayiç, 2008; Varol, 2014). Direct teaching is a structured teaching method based on behavioral approaches such as sequencing the content to be taught in a consecutive way, encouraging full participation of students, giving them corrective feedback, using cueing strategies, utilizing skill analyses and reinforcing correct responses (Dağseven-Emecen, 2008; Gersten, 1985; Güzel, 1998). Four steps involved in this method are often mentioned in the literature. These are (a) having a warm-up to attract attention and create necessity, (b) modeling a target skill or presenting an appropriate model to students, (c) doing practices accompanied with cueing strategies and corrective feedback, and (d) having students do independent practices by giving them full responsibility (Alptekin, 2010; Baumann, 1984; Dağseven, 2001; Dağseven-Emecen, 2008; Güzel, 1998).

This method emphasizes understandable and clear narratives, modeling, and guided practices (Heilman, Blair, \& Rupley, 2002; Blair, Rupley, \& Nichols, 2007). As suggested by the name, modeling is showing the stages of the target skills. Various representations and narratives about when and how to perform the skills in real situations can be provided in this stage (Blair et al., 2007; Baumann, 1984). Thanks to the development of technology, videos or animations about any skill to be taught can be shown in addition to the demonstrations in which teachers or peers take role (Dağseven-Emecen, 2008). In this study, a first aid training package was created based on the direct teaching method. Digital stories about the first aid skills to be taught were created by the researchers.

Digital stories, which are limited to a few minutes, include various multimedia elements such as music, text, video, audio and graphics, and they aim to educate people about a particular topic (Robin, 2006). These next-generation stories also enable us to blend traditional storytelling with a modern and technological approach (Wang \& Zhan, 2010). Although there are studies about the use of digital stories in order to teach academic skills like reading and writing in the literature (Morgan, 2014; Yamaç, 2015), research on their use to teach students with intellectual disability is quite limited. Digital storytelling is said to increase student motivation and aspiration (Sümer \& Eldeniz-Çetin, 2017; Yang \& Wu, 2012). However, no study examining the effectiveness of a safety skills training package, which includes digital stories to provide individuals with intellectual or developmental disabilities with a model and which is based on the direct teaching method, has been encountered. In this sense, it is believed that 
such a study will contribute to the experts working in the field of special education in terms of teaching safety skills by providing them with an alternative method. The purpose of this study is to teach simple first aid skills through direct teaching method using a training package that combines both informative and behavioral skills training, which is also a suggestion in the field literature (Miltenberger et al., 2015)

While it is essential that programs at schools should include objectives related to the first aid skills, it is observed that these skills are not given enough importance in school environment; they are not even included in some programs and there is not enough emphasis on their practice even if the program covers them (Carruth et al., 2010; Ergenekon, 2012). However, due to the importance of even seconds in first aid, some health services should not be left to the hands of health officials only; individuals should also take responsibility whenever necessary (Nayir, Uskun, Türkoğlu, Uzun, \& Öztürk, 2015). For this reason, individuals with intellectual disability, whom we want to be a part of our society, should be given necessary training on first aid. In accordance with the reasons listed above, such a study has been found to be necessary. The aim of this research is to evaluate the effectiveness of a training package whose modeling stage includes digital stories, modeling and a first aid manikin in teaching simple first aid skills for cuts, sprains and bee stings through direct teaching method. For this purpose, the research questions have been determined as follows: (a) Is the training package prepared for teaching simple first aid skills to individuals with intellectual and additional disabilities effective? (b) Do the participants maintain the target skills for 1, 3, and 4 weeks after the completion training? (c) Can the participants generalize the target skills to different practitioners, settings and materials? (d) What are the opinions of the participants and their families regarding the research?

\section{Method}

\subsection{Participants}

Two male and one female student diagnosed with mild intellectual disability and selected by the counseling and research center participated in the study. Code names were used for students during the reporting stage of the research. All the participants were enrolled in the middle-school level special education class, and they taking elective courses such as visual arts, music, physical education, religion and etc. with their peers in accordance with the planning made by a special education teacher, school counselor and administration. The required written and verbal consent was obtained from the participants' families before the study. Table 1 gives information about the participants.

Table 1. Information about the participants

\begin{tabular}{|c|c|c|c|c|}
\hline $\begin{array}{l}\text { Participant's } \\
\text { Name }\end{array}$ & Age & Diagnosis & Class & Additional Disability \\
\hline Mahmut & 12 years 2 months & $\begin{array}{l}\text { Mild Intellectual Disability } \\
\text { (MID) }\end{array}$ & 7. Grade & $\begin{array}{l}\text { Attention Deficit Hyperactivity Disorder } \\
\text { (ADHD) }\end{array}$ \\
\hline Nazan & 15 years 3 months & $\begin{array}{l}\text { Mild Intellectual Disability } \\
\text { (MID) }\end{array}$ & 8. Grade & Vision Impairment \\
\hline Serkan & 13 years 2 months & $\begin{array}{l}\text { Mild Intellectual Disability } \\
\text { (MID) }\end{array}$ & 7. Grade & Epilepsy \\
\hline
\end{tabular}

Mahmut was a 12-year-old male student. He had been diagnosed with ADHD and intellectual disability. He used his medication given by the psychiatric service for ADHD once every day. He possessed the self-care skills and was able to perform them independently; he had no orthopedic disability or vision/hearing impairment. Mahmut could add a four-digit number with another one, two, three or four-digit number in a way including a singular carry or multiple carries. In addition, he could subtract a one, two, three or four-digit number from a four-digit number in a way including a singular decimal or multiple decimals. He could answer simple $5 \mathrm{~W} 1 \mathrm{H}$ questions about texts consisting of an average of 15 sentences, summarize stories consisting of 15-20 sentences in 3-4 sentences, and explain events he had experienced in 4-5 sentences. He could dictate a text composed of 40-45 sentences with a maximum of one error. Furthermore, he could dictate words consisting of 3-5 phonemes with maximum 1 error. He mostly had difficulty in dictating the "c, ç, s, ş, p and b" sounds in those words. He was likely to forget the days of the week and the date in two of the 5 school days. He also had limitations in some social skills.

Nazan was a 15 -year-old female student. In addition to intellectual disability, she was wearing corrective glasses prescribed level "9" due to visual impairment. She could perform all self-care skills except having a bath because of her glasses, so she sought help from her mother for that. She could also add a four-digit number with a one, two, 
three or four-digit number in a way including a singular carry or multiple carries; she could subtract a one, two, three or four-digit number from a four-digit number in a way including a singular decimal or multiple decimals. In addition, she could multiply a two-digit number with another two-digit number without carry. She was able to answer simple $5 \mathrm{~W} 1 \mathrm{H}$ questions about texts consisting of an average of 40 sentences, summarize stories consisting of 50-55 sentences in 6-7 sentences, and explain events she had experienced in 8-9 sentences. She could dictate a text composed of 60-65 sentences with a maximum of two errors and words consisting of 5-7 phonemes with maximum 1 error. She had difficulty with small and large set of phonemes mostly. She was likely to forget the days of the week and the date in two out of 5 school days. Also, she has limitations regarding some social skills.

Serkan was a 13-year-old male student. In addition to intellectual disability, he was suffering from epilepsy. He was reported to have had facial paralysis by his family, which was also included in his school records. He had not been taking any medication on a regular basis for the last 4 years. He possessed the self-care skills and he was able to perform those skills independently; he did not have any orthopedic disability or vision/hearing impairment. Serkan could add a four-digit number with a one, two, three or four-digit number in a way including a singular carry or multiple carries. Also, he could subtract a one, two, three or four-digit number from a four-digit number in a way including a singular decimal or multiple decimals. He could also multiply a two-digit number with a single-digit number without carry. He was able to answer simple $5 \mathrm{~W} 1 \mathrm{H}$ questions about texts consisting of an average of 25 sentences, summarize stories consisting of 30-35 sentences in 5-6 sentences, and explain events he had experienced in 7-8 sentences. He could dictate a text composed of 55-65 sentences with a maximum of two errors. He could dictate words consisting of 4-6 phonemes with maximum 1 error, as well. He had difficulty dictating the " $\mathrm{z}$ and s" sounds in those words mostly. He was likely to forget the days of the week and the date in one of the 5 school days, and he had some limitations regarding some social skills.

None of the participants had been involved in any kind of first aid training, which was also approved by their parents, and they were not able to answer any relevant question prior to the implementation of this study. This constitutes an important element in determining the functional relationship of this study.

\subsection{Setting}

This study was conducted in a middle school located in a town in İstanbul, where socio-economic level was low, and there were a number of immigrants. The baseline, intervention and maintenance sessions took place in an underutilized room of the school which was reserved for the principal. Since that room was designated as the only suitable place for the study, it was preferred and used upon the approval of the school administration. It was a $8 * 4$ $\mathrm{m} 2$ rectangular room facing the south with enough heat and light as well as sufficient isolation. There were two tables (one small, one big), eight chairs, a two-seater sofa, two single-seat sofas, one paper cabinet, one bookcase, one first-aid cabinet, one photocopier, one computer and one air conditioner in the room. The intervention phases were held around the big table as a group activity.

The generalization sessions were conducted in the resource room. One of the walls in that room was plastic whereas the others were concrete. In that room, there were eight wooden tables and chairs for students, a set of tables and a chair for the teacher, a four-door wooden cabinet with two glass doors and a metallic heater. A white light bulb and 2 windows were present at the midpoint of the ceiling. The room was light and warm enough, and it was sufficiently insulated against noise in a way not distracting either the practitioner or the participants during the study. There were no objects like paintings or activities on the walls in the classroom, which would be distractive, either. This room in which the generalization sessions were conducted was being used as an educational support center for inclusive students on a regular basis.

\subsection{Equipment}

The research aimed to teach three basic first aid skills. White gauze bandages and red magic markers were used to teach first aid skills in case of a simple cut. The size of the gauze bandages was $7.5 * 7.5 \mathrm{~cm}$. For the second skill, which was doing first aid in case of a bee sting, a black thread, scissors, glue, a sink model (made by the researchers) and 0.5 liter ice bottle were used. As for sprains, a 0.5 liter ice bottle and a $10 \mathrm{~cm} * 3.5 \mathrm{~m}$ bandage were used to teach first aid skills. All sessions of the study were recorded by the researchers on video, for which a mobile phone with a camera was used. Also, a laptop computer was utilized to show digital stories.

\subsection{Practitioner}

The implementation process was held by the second author of the study. He has both B.A. and M.A. degrees in the field of special education and is pursuing $\mathrm{PhD}$ studies in the same field. He has considerable experience in systematic implementation and is a special education teacher working in a school affiliated to the Ministry of Education (MEB). He has 8 years of experience in working with children with intellectual and developmental 
disabilities.

\subsection{Research Model}

A multiple probe design across behaviors with probe conditions, one of the single-subject designs, was employed in this study to evaluate the effectiveness of the training package prepared to teach first aid skills. In this method, experimental control is established when there is an increase in the amount of correct behaviors of the first participant, while there is no significant change in the behaviors for which no intervention is made and when the same situation is observed for the other participants in the same manner and order (Tekin-Iftar, 2012). The independent variable of the study was training package and the dependent variables of the study were the participants' level of acquisition of the target skills (cut, sprain and bee sting).

\subsection{Implementation}

\subsubsection{Preparation of the Digital Stories}

The implementation process started with the creation of scripts and digital stories. Barrett (2009) lists the steps to be followed to create a digital story as "writing a script, recording audio, identifying visuals, combining sound and image, putting everything together and releasing the story."

1) Script writing: The stories were written in accordance with the target skills and in a way including every single sub-skill. Their stories, which consisted of 266, 254, and 242 words respectively, were close to each other in terms of length. For the names to be involved in the stories, the students' suggestions were taken up and used. Upon their completion, each story was read by all the authors and necessary corrections were made. They were finalized by asking for expert opinion from another researcher experienced in digital storytelling.

2) Audio recording: Audio recording that is consistent with the script and flow is important in digital storytelling. For this purpose, audio recordings were prepared by a researcher experienced in both digital story program and creation.

3) Identifying visuals: Visuals have a big role in digital stories. Therefore, pictures that would attract the participants' attention were used in the stories. The visuals consisted of original pictures created for this research. Another important aspect of the visuals used in this study was that they visually explained each sub-skill determined through the skills analysis. In other words, each step of the analysis was defined to the students both verbally and visually.

4) Combining sound and image: At this stage, sound and image to be used in a story are combined. It is suggested that frequently used video programs may be preferred for this purpose. For example, iMovie can be a tool for Macintosh users, while MovieMaker2 is recommended for Windows users.

5) Bringing everything together: What has been prepared so far is put together at this stage of digital story making. In this study, the audio recordings, visuals and writings on the visuals were gathered together; background music and other necessary elements were added to finalize the digital story at this stage.

6) Release: It is recommended that stories in different formats ( $\mathrm{mp} 4$, wmv etc.) be used either online or off-line. In this study, the digital story in mp4 format was shown using "vlc player". According to Sümer and Eldeniz-Çetin (2017), such stories should not be longer that 5 minutes in order not to cause boredom. In accordance with this suggestion, the stories used in the study were 2.27, 2.33, and 2.26 minute-long.

\subsubsection{Baseline Data Collection}

These sessions were held in the same room, where the intervention sessions were done. A similar situation to the one given in the digital stories was told the participants, and they were asked to explain what they would do in such a situation. None of the participants were able to respond in the way expected considering the target skills. Their responses were recorded on both video and data collection form by the practitioner.

\subsubsection{Implementation of the Independent Variable}

The digital stories were planned to be used during the intervention phase of the study through direct teaching method. The implementation was conducted in a small group format and there were three students with mild intellectual disability (MID), one of whom was female. For the classes to be held through direct teaching method, skills analysis was done first, and then teaching units were prepared in accordance with the analysis. While developing those teaching units, studies related to direct teaching method were reviewed in the field. The units were prepared as follows considering those studies (Alptekin, 2010; Baumann, 1984, Dağseven, 2001; Güzel, 1998): 1) Introduction to the course and awareness creation, 2) Modeling, 3) Guided practice, 4) Independent 
practices and evaluation. The implementation chart of the training package is shown in Figure 1.

Introduction to the course and awareness creation: At this stage of the implementation, the practitioner informed the students about the rules, reinforcement and the flow of the course. Afterwards, some explanations were given in order to attract their attention to the target skills and create awareness. They were given information about the vital importance of these skills, the situations in which they could use the skills, and their necessity to save others' lives. In addition, they were told that they would be able to do first aid once they acquired those skills, which would also ensure their safety.

Modeling: This step was realized in three stages: a) The digital story prepared to teach the target skills were shown to the students, and they were carefully monitored to be sure that they were paying enough attention to the video, b) the practitioner created an analogy situation about the skill for which awareness had been created and s/he did first aid on a manikin to model the target behavior, and c) finally, s/he showed the target behavior on his/her own body. In the meantime, the students were asked questions about the stages constituting the whole process. Thus, they were encouraged to think about the process while each stage was being defined in a detailed way.

Guided practice: This phase involved the students' practicing the skill on their own body under the guidance and leadership of the practitioner. The practitioner provided as many prompts as needed (as few as possible) and their responses, whether prompted or not, was both reinforced. The responses given without any prompt were reinforced more. That's, independent responses were reinforced in a distinctive way. Also, the students were motivated and encouraged to perform the skill by the practitioner. Each student, who was being carefully watched by their peers, performed the skill in turn, which had been determined by consulting the students. When a student needed too many prompts, the practitioner modelled the skill once more before continuing the cycle with the next student. Furthermore, the ones who did not perform the skills were reinforced for their attention to the course and interest in it, as well.

Independent practices and evaluation: Once the students repeated the skill once or twice if deemed necessary, the independent practices phase was initiated. In this phase, each student had a one-to-one performance with the practitioner while the others were watching them. Evaluation of the target skills was also made in this phase. Each student was given an instruction relevant to the skills which had been taught (E.g.: Serkan, you have a bee sting! Why don't you do first aid?). Without providing the student with any prompt or assistance, her/his performance was evaluated, and the responses were recorded as correct and incorrect. Similar to the baseline level, single-opportunity method was used in the evaluation stage. As a requirement of this method, both the evaluation and teaching sessions were terminated as of the first incorrect response given by a student, and the remaining steps were recorded as a false response. Following the evaluation phase, the students were verbally reinforced for their participation and performance by the practitioner.

\begin{tabular}{|c|l|}
\hline Introduction & $\begin{array}{l}\text { - Introduction to the course } \\
\text { - Awareness creation }\end{array}$ \\
\hline Modeling & $\begin{array}{l}\text { - Digital story } \\
\text { - Symbolic model (First aid manikin) } \\
\text { - Live Model } \\
\text { - Reinforcement of positive responses }\end{array}$ \\
\hline - Practice under teacher guidance \\
\hline Independent & $\begin{array}{l}\text { - Fading prompts } \\
\text { - Reinforcement of positive responses }\end{array}$ \\
\hline Practices & \begin{tabular}{l} 
- Students' independent practices \\
\hline
\end{tabular} \\
\hline
\end{tabular}

Figure 1. Implementation scheme

\subsubsection{Maintenance and Generalization Sessions}

While the intervention sessions of the study were conducted in small group format, the maintenance sessions were held in a one-to-one way. The generalization sessions were held after 1, 3 and 4 weeks once the criteria were met for each target skill and they were also videotaped. Similar to the independent practices, the participant was given an instruction following an attention-grabber prompt, and s/he was expected to perform the skill. Data collected in the maintenance sessions were processed by the practitioner onto data record forms and graphs. When the participants performed the target skills accurately, it was reinforced at the end of these sessions. 
The generalization sessions were conducted in the same school's resource room and carried out in a one-to-one format similar to the maintenance sessions. At the end of these sessions, when the participants performed the target skills accurately, it was reinforced, as well. The purpose of the generalization sessions was to evaluate whether the participants could transfer the acquired skills to a different setting, practitioner and material (other first aid tools with different size and shape). The practitioner who held these sessions was a special education teacher with a BA degree and seven-year of experience in the same field.

\subsection{Dependent Variables}

The training package used in this study aimed to teach simple first aid skills for cuts, sprains, and bee stings. The dependent variable of the study was the participants' level of acquisition of the target skills. All of these skills are also included in the academic program which is designed for students with mild intellectual disability and followed at special education vocational training centers affiliated to the Ministry of National Education as a part of social sciences course (Objective: 21) (MEB, 2017a). When the subjects of the first aid and traffic courses offered to students with moderate and severe intellectual disability at special education centers are examined, it can be seen that objectives about simple injuries are covered (Objective: 26), while the other dependent variables of this study are not (MEB, 2017b). There are also some simple animation videos prepared by The Turkish Red Crescent to teach some basic first aid skills to children. The first aid skills that are intended to be taught within the scope of this study are also among those skills (Türk Kizılay, 2016). While choosing the dependent variables, that's, the target skills, of this study, these processes were also taken into consideration. Moreover, the second author of this study, who was working in the special education class in which the participants were enrolled in, determined that these skills had never been studied before though a document review. Furthermore, the interviews conducted with the participants' families also revealed that the participants had never been taught those skills in the house or in any educational setting.

Before analyzing the skills chosen as the dependent variables of the research, various books and internet addresses released by the Turkish Red Crescent were examined and a medical doctor was consulted. After the skill analysis was prepared, it was reconsidered by each researcher separately and it was finalized by consulting a medical doctor once more. The analysis of the skills associated with the dependent variables of this study has been given below.

\section{Skill Analysis}

Cut

1) $\mathrm{S} / \mathrm{He}$ goes to the first-aid cabinet.

2) $\mathrm{S} / \mathrm{He}$ gets a gauze bandage.

3) $\mathrm{S} / \mathrm{He}$ says if there is no gauze bandage, s/he'll get a clean outfit.

4) $\mathrm{S} / \mathrm{He}$ compresses the gauze bandage onto the bleeding area.

5) $\mathrm{S} / \mathrm{He}$ says that a new one is to be put on the gauze bandage if it is covered with blood all over.

6) $\mathrm{S} / \mathrm{He}$ puts another gauze bandage.

7) $\mathrm{S} / \mathrm{He}$ goes to the nearest place where $\mathrm{s} / \mathrm{he}$ can sit.

8) $\mathrm{S} / \mathrm{He}$ keeps the cut above his heart level.

9) $\mathrm{S} / \mathrm{He}$ informs the nearest adult.

10) $\mathrm{S} / \mathrm{He}$ says s/he'll call 112 emergency service if bleeding does not stop.

\section{Sprain}

1) $\mathrm{S} / \mathrm{He}$ says $\mathrm{s} /$ he won't move the sprained part.

2) $\mathrm{S} / \mathrm{He}$ does not move the sprained part.

3) $\mathrm{S} / \mathrm{He}$ takes ice from the fridge.

4) $\mathrm{S} / \mathrm{He}$ sits in the nearest place.

5) $\mathrm{S} / \mathrm{He}$ put the ice on and around the sprained area for about 15 minutes.

6) $\mathrm{S} / \mathrm{He}$ gets a bandage from the first-aid cabinet.

7) $\mathrm{S} / \mathrm{He}$ wraps the bandage around the sprain for four or five times.

8) $\mathrm{S} / \mathrm{He}$ goes to the nearest bed or seat.

9) $\mathrm{S} / \mathrm{He}$ lies on it in a way holding the sprain above his/her body. 
10) $\mathrm{S} / \mathrm{He}$ informs an adult $\mathrm{s} / \mathrm{he}$ can reach.

11) $\mathrm{S} / \mathrm{He}$ says $\mathrm{s} /$ he should call 112 emergency service if the pain gets more.

Bee sting

1) $\mathrm{S} / \mathrm{He}$ says $\mathrm{s} / \mathrm{he}$ will remove the stinger if visible.

2) $\mathrm{S} / \mathrm{He}$ removes it.

3) $\mathrm{S} / \mathrm{He}$ goes to the sink.

4) $\mathrm{S} / \mathrm{He}$ washes the wounded area.

5) $\mathrm{S} / \mathrm{He}$ goes to the fridge.

6) $\mathrm{S} / \mathrm{He}$ takes some ice from the fridge.

7) $\mathrm{S} / \mathrm{He}$ sits in the nearest place.

8) $\mathrm{S} / \mathrm{He}$ puts the ice on the wound.

9) $\mathrm{S} / \mathrm{He}$ says $\mathrm{s} / \mathrm{he}$ 'll wait for 10 minutes.

10) $\mathrm{S} / \mathrm{He}$ informs the nearest adult.

11) $\mathrm{S} / \mathrm{He}$ says $\mathrm{s} / \mathrm{he}$ should call 112 emergency service if $\mathrm{s} / \mathrm{he}$ cannot breathe.

\subsection{Reliability}

In this study, which aims to evaluate the effectiveness of a training package including digital stories in teaching first aid skills to individuals with intellectual disability through direct teaching method, some reliability data were collected. During the research, all sessions were recorded on video. In the literature, it is recommended that data on inter-rater reliability and over-time reliability be collected in no less than $20 \%$ of the sessions. Therefore, all sessions included in the study were numbered and reliability data were collected in $20 \%$ of them, which were determined with random method. The data were collected by an observer who was a faculty member in the field of special education. The observer who had previously been involved in other studies as an observer had relevant experience. Data collection forms for both inter-rater reliability and over-time reliability were prepared to record data.

\subsection{Social Validity}

When the literature is reviewed, it can be seen that the studies on validity and relevant suggestions date back more than 40 years ago. Considering the fact that one of the main purposes of conducting research is to produce socially valuable outcomes, it is essential to develop some systems to query whether this aim is achieved (Wolf, 1978). To determine the social validity of single subject research, the appropriateness of target skills, tools employed to reach those targets and findings obtained as a result of a study should be evaluated. Social validity can be measured in two forms: subjective evaluation and normative comparison (Tekin-iftar, 2012). Subjective evaluation, which is a more common way of collecting social validity data, attempts to identify the opinions of individuals who are somehow associated with a study regarding the purpose, method and results of the study. This evaluation is done by asking questions about the purpose, method and results (all or some) of the study (Kurt, 2012). This study was also based on the subjective evaluation method. Firstly, the participants and their families were interviewed. A social validity form consisting of three questions addressing each group was created. These one-to-one interviews were conducted during out-of-class hours.

\section{Findings}

The findings about Mahmut, Serkan and Nazan obtained in this study, which examined the effectiveness of a training package consisting of digital stories and direct teaching method in teaching first aid skills to individuals with intellectual disabilities, are shown in Figures 2, 3, and 4. Although the intervention sessions were held in a small group format, the findings were given separately since the evaluations had been carried out individually.

The first skill to be taught was determined as doing first aid for simple cuts, and individual baseline sessions were held with the participants. In accordance with the model of the study, baseline data was collected until stable data was achieved with all participants. For the other skills, baseline data was collected in one session with each participant.

\subsection{Findings on Effectiveness}

The percentages representing the correct responses given by Mahmut, Nazan, and Serkan during the baseline, intervention, generalization and maintenance sessions are given in Figures 2, 3, and 4 respectively. The sessions of 
the intervention phase, that is the training phase, were held in a small group format. After these sessions, one-to-one sessions were conducted for evaluation, and the results were transferred to visuals.

The first skill to be covered was determined randomly, and the implementation started. The first skill to be dealt with in the research was the ability to do first aid for cuts. During the baseline sessions, the performances of all participants, Mahmut, Nazan, and Serkan, were measured as $0 \%$. The intervention stage started when stable data were collected from each participant during the baseline phase. During the intervention, eight sessions in a small group format were held. After those sessions, all the participants met the criteria and performed $100 \%$. Then, the second target skill, doing first aid for bee stings, was studied. Stable data was obtained with the subjects at the baseline phase and all participants' performances were measured as $0 \%$. In the intervention phase, a total of seven sessions were conducted. At the end of those sessions, all of the performances were measured as $100 \%$. The last skill studied was doing first aid for sprains. During the baseline phase, all subjects performed at $0 \%$ level and stable data was obtained. Following seven intervention sessions held in a small group format, their performance increased to $100 \%$ and they all met the criteria. Maintenance sessions were held after 1, 3, and 5 weeks following the completion of intervention phase. It was observed that their ability to perform the target skills was still at $100 \%$ level.

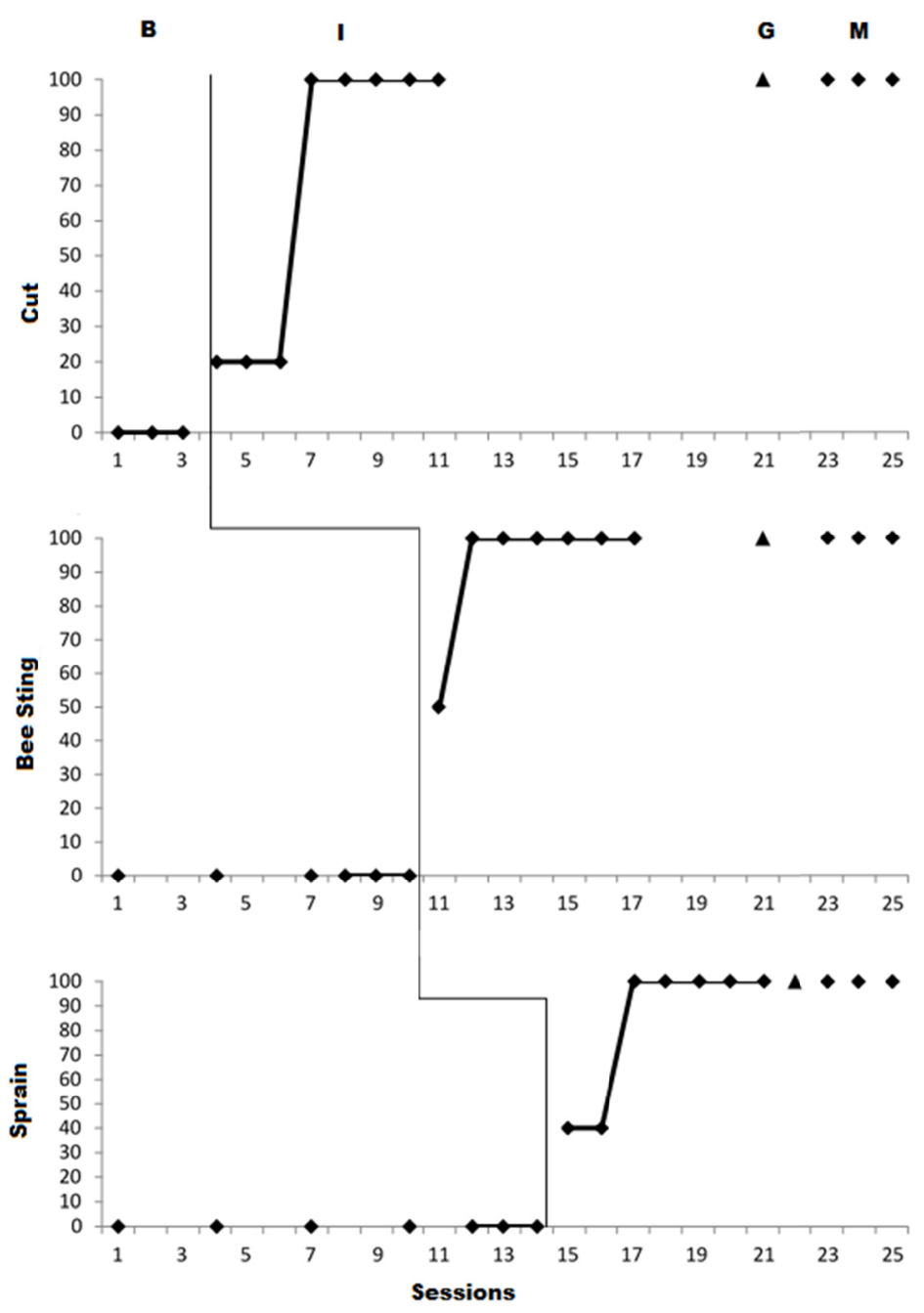

Figure 2. The percentages of the correct responses given by Mahmut during the Baseline (B), Intervention (I), Maintenance (M), and Generalization (G) sessions 


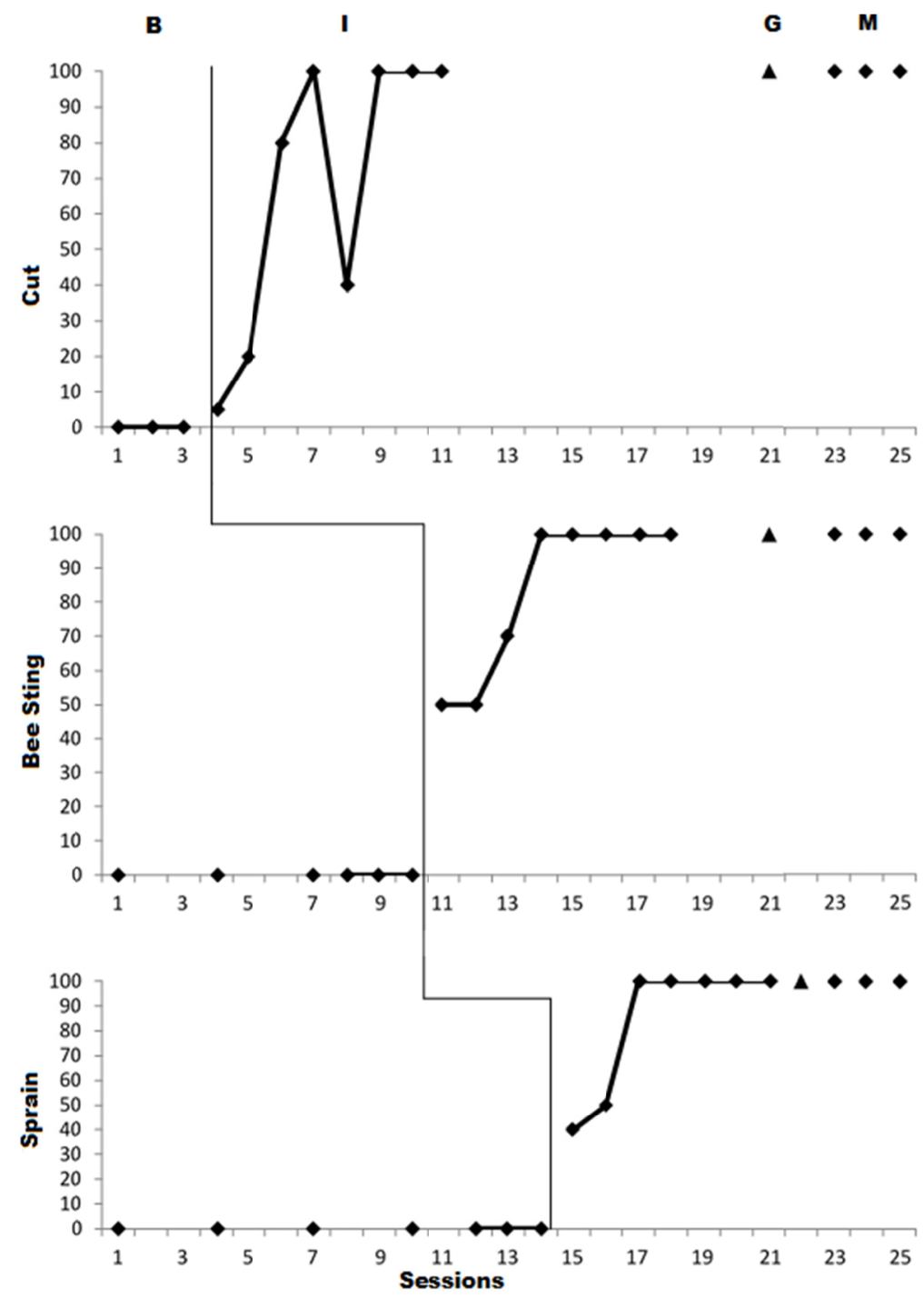

Figure 3. The percentages of the correct responses given by Nazan during the Baseline (B), Intervention (I), Maintenance (M), and Generalization (G) sessions 


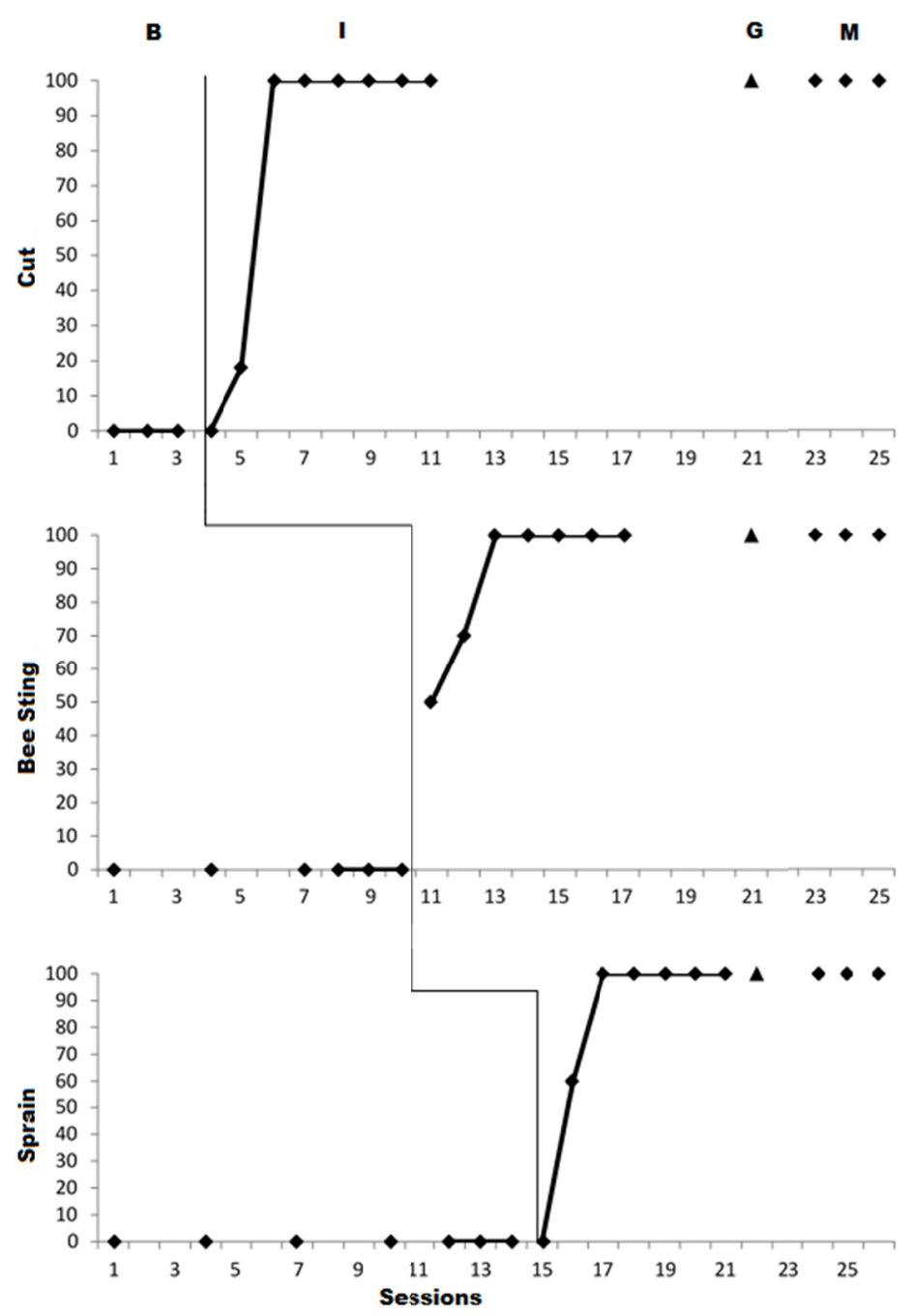

Figure 4. The percentages of the correct responses given by Serkan during the Baseline (B), Intervention (I), Maintenance $(\mathrm{M})$, and Generalization $(\mathrm{G})$ sessions

\subsection{Generalization}

The one-to-one generalization sessions were conducted in the educational support room of the school. Different settings, practitioner and materials were arranged for these sessions, and the participants' ability to generalize the acquired skills was determined. The findings revealed that all of the participants were able to generalize the first aid skills necessary in case of a cut, bee sting and sprain at $100 \%$ level.

\subsection{Social Validity}

The social validity data of the study was obtained through interviews done with both the participants and their families. They were asked open-ended questions. The interviews showed that they were happy with the study. In addition, it was observed that the participants had enjoyed the course and watching the videos on computer. They were also pleased that their teachers had prepared a digital story for them. Likewise, the interviews with the families showed that they were glad that their children had learned those vital skills, which gave them a relief. Furthermore, the families were eager to let their children take part in other studies on security skills as they believed such skills were to be taught to children.

\section{Reliability}

Reliability data on both the dependent and independent variables of the study were collected by the researchers. Inter-rater reliability data was collected for the dependent variable whereas over-time reliability was obtained for the independent variable. In the literature, it is suggested that data on both reliability types be collected in single-subject research (Horner et al., 2005; Kratochwill et al., 2013). The data achieved in line with this is as 
follows.

\subsection{Inter-Rater Reliability}

One set of the data collected in the study was about the inter-rater reliability. It was collected using the formula "Agreement/(Agreement+ Disagreement) x 100". It is recommended that inter-rater reliability data be collected in at least $20 \%$ of all sessions or at least once in each phase (Erbaş, 2012). The data on the inter-rater reliability are shown in Table 2.

Table 2. Findings on inter-rater reliability

\begin{tabular}{ccccc}
\hline Target Skills & Baseline & Intervention & Generalization & Maintenance \\
\hline Cut & $100 \%$ & $100 \%$ & $100 \%$ & $100 \%$ \\
Sprain & $100 \%$ & $100 \%$ & $100 \%$ & $100 \%$ \\
Bee sting & $100 \%$ & $100 \%$ & $100 \%$ & $100 \%$ \\
\hline
\end{tabular}

\subsection{Over-Time Reliability}

The observer monitored and evaluated whether the intervention was being applied as planned by the practitioner or not. Before collecting over-time reliability data, expected behaviors from the practitioner were determined by the researchers. Over-time reliability was collected to determine whether the implementation was carried out as planned by the practitioner. The formula "Observed behavior/Planned behavior X 100" was used to analyze over-time reliability data (Erbaş, 2012).

Table 3. Findings on over-time reliability

\begin{tabular}{ccccc}
\hline Target Skills & Baseline & Intervention & Generalization & Maintenance \\
\hline Cut & $100 \%$ & $100 \%$ & $100 \%$ & $100 \%$ \\
Sprain & $100 \%$ & $100 \%$ & $100 \%$ & $100 \%$ \\
Bee sting & $100 \%$ & $100 \%$ & $100 \%$ & $100 \%$ \\
\hline
\end{tabular}

\section{Discussion and Conclusion}

The purpose of this study is to evaluate the effectiveness of a teaching package which is based on the use of digital stories in the modeling phase and offered through direct teaching method in teaching first aid skills to individuals with intellectual disability. In addition, the maintenance level of the acquired skills for 1, 3, and 4 weeks after the completion of the intervention has been examined as well as their generalization to other settings, materials and practitioner. Besides, social validity data has been collected by inquiring about the participants and their families' opinions of the study.

The study has revealed that the participants have learned the target skills and met the criteria set by the researchers. Since those skills are all about safety, the criteria of the research have been determined as $100 \%$. Also, it has been observed that the training package including digital stories offered through direct teaching method is effective in teaching the target safety skills to all three participants with intellectual disability. In the literature, there is no research on the independent variable studied by the researchers in this study. In other words, no study based on the use direct teaching method to teach first aid or safety skills through digital storytelling to individuals with intellectual disability has been found in the literature. Therefore, the study has been discussed within the scope of its dependent variable, first ad skills.

When the graphical analysis of the data collected from the participants is examined, it can be observed that all three participants have met the criteria for all three target skills. The participants have acquired the first aid skills by performing all steps decided by analyzing the target skills. This research has findings that support relevant studies aimed at teaching first aid skills to students with different disabilities such as developmental and intellectual disability (Christensen et al., 1993; Ergenekon, 2012; Gast, Winterling, \& Wolery, 1992; Marchand-Martella \& Martella, 1990; Marchand-Martella et al., 1992; Kearney et al., 2018; Spooner, Stem, \& Test, 1989; Timko \& Sainato, 1999). In a similar study, Gast et al. (1992) examined the effectiveness of a training package in teaching first aid skills through constant time delay procedure to students with intellectual disability with a small group format. Their study revealed that the students were able to learn the target skills. In another study conducted with a small group format, Timko and Sainato (1999) aimed to evaluate the effectiveness of various combinations of 
modeling and rehearsing in teaching first aid skills to children with intellectual and developmental disability. They found out that all the participants acquired the target skills as well as asking for help from an adult. Therefore, this study can be said to be consistent with other research about teaching first aid skills through small group format with respect to the acquisition of the dependent variable. In another study, Ergenekon (2012) aimed to determine the effectiveness of video modeling in teaching first aid skills to three students with developmental disability. It was observed that all participants successfully achieved the target. In addition, Marchand-Martella et al. (1992) used social learning method to teach four participants with intellectual disability how to do first aid to simple scratches using their body and a manikin. All the participants in their study were reported to have acquired the skills at the end. The findings of their study, which was also conducted in a one-to-one way, are consistent with this study's findings. In the light of the information above, it can be concluded that individuals with intellectual disability can learn first aid skills through appropriate methods as long as those skills are well analyzed and compatible with their level.

Following the intervention sessions, maintenance sessions were also held in the study. All participants successfully performed the target skills in these sessions $(100 \%)$. Based on these data, it can be said that the independent variable of the study is also effective in ensuring the independent maintenance of the skills for a certain time period. Considering the skill maintenance ability of the participants despite their intellectual disability, it is believed that a training package including the use of digital stories during the modeling phase, which is applied through direct teaching method, can be a useful option for other experts and teachers who are willing to teach safety skills, especially first aid skills. When the studies on teaching safety skills available in the field literature are reviewed, it can be seen that there are some consistent findings with this study. Kearney et al. (2018) found out that the reading-oriented training package they used in their study was effective in providing the maintenance of target skills at a level of $86 \%$. Likewise, Spooner et al. (1989) collected maintenance data at the end of the intervention phase in their study which aimed at teaching first aid skills. When the graphical analysis of that study is examined, similar findings can be observed. However, the findings of another study conducted by Gast, Winterling, and Wolery (1992) were different in that the participants maintained the target skills at that much lower level. With this respect, they are not consistent with the findings of this study. It may be due to that they spent a longer time to collect data. As for generalization, the findings are similar to other studies which were done in a small group format (Timko \& Sainato, 1999) and one-to-one format (Ergenekon, 2012). It's essential that whether first aid skills can be generalized to other settings, practitioners and materials be determined. In this study, the participants have been able to generalize the target skills to a great extent.

In addition, social validity data related to the dependent and independent variable used in the research have been collected with subjective evaluation method. When the literature is reviewed, it can be seen that some researchers like Marchand-Martella et al. (1992) and Ergenekon (2012) employed normative comparison for this purpose. In addition, there are other studies in which professional medical employees were targeted to evaluate social validity (Gast et al., 1992). Therefore, this research differs from those studies (Marchand-Martella et al., 1992; Ergenekon, 2012; Gast et al., 1992) in terms of social validity data. However, Timko and Sainato (1999) chose to use subjective evaluation to collect social validity data similar to this study. Both studies revealed positive opinions regarding the studies. When the social validity data of this study is examined, it can be observed that both the participants and their parents have expressed high satisfaction with the study. Especially the participants seem to be glad to have a training package including digital stories, which was both observed during the implementation process and expressed by the participants during the interviews held for social validity purposes. This finding is believed to prove the importance of digital stories in teaching not only first aid skills but also other skills. It is recommended that digital stories be used as a backup and enrichment in the education of individuals with intellectual disability, which can also let them enjoy the education.

An inevitable dimension of the research process is limitations, and this research also has certain limitations, one of which is that no data has been collected during the intervention phase. Some studies on teaching first aid skills define the duration in which participants acquire the first aid skills since the length of intervention is believed to matter (Marchand-Martella et al., 1992; Marchand-Martella et al., 1993). However, this hasn't been taken into consideration in this study, and no social validity collected through normative comparison is available. Another limitation to this study is that unreal injuries has been used as the dependent variable since it is quite challenging to find and use real injuries although it is desirable. In a real-life situation, it is likely that the participants may not perform as well as they have done in the study due to excitement, stress and fear. Moreover, this study is limited to three first aid skills- cuts, sprains and bee stings. Although it would be more appropriate to study all the skills determined by the Turkish Red Crescent or the Ministry of Education National, only three of them have been covered due to constraints of time and place. It is suggested that further research can be conducted to evaluate the 
effectiveness of the use of digital storytelling during modeling phase of a training package offered through direct teaching method in teaching other first aid skills like simple burns and poisoning. Finally, teaching other safety skills such as fire safety skills, earthquake safety skills, personal safety skills, and pedestrian safety skills can be aimed in other research.

\section{References}

AAIDD. (2019). American association on intellectual and developmental disability. Retrieved from http://www.aaidd.org/intellectual-disability/definition

Agran, M., Krupp, M., Spooner, F., \& Zakas, T. L. (2012). Asking students about the importance of safety skills instruction: A preliminary analysis of what they think is important. Research and Practice for Persons with Severe Disabilities, 37(1), 45-52. https://doi.org/10.2511/027494812800903265

Agran, M., Spooner, F., \& Zakas, T. L. (2008). Health and Safety Adaptive Skill Area. In T. Oakland, \& P. L. Harrison (Eds.), Adaptive behavior assessment system-II: Clinical use and interpretation (pp. 137-157). https://doi.org/10.1016/B978-012373586-7.00008-4

Alptekin, S. (2010). Akranların sosyal becerilere model olduğu doğrudan öğretimin zihinsel engelli öğrencinin sosyal becerileri kazanması, sürdürmesi, genellemesi ve sosyal kabulüne etkisi (Yayımlanmamış Doktora Tezi). Gazi Üniversitesi Eğitim Bilimleri Enstitüsü, Ankara.

Ataman, A. (2003). Özel gereksinimli çocuklar ve özel eğitim. In A. Ataman (Ed.), Özel gereksinimli çocuklar ve özel eğitime giriş (pp. 9-31). Ankara: Gündüz Eğitim ve Yayıncılık.

Bambara, L. M., Browder, D. M., \& Koger, F. (2006). Home and community. In M. E. Snell, \& F. Brown (Eds.), Instruction of students with severe disabilities (pp. 529-568). Upper Saddle River, NJ: Prentice Hall.

Barrett, H. (2009). How to create simple digital stories. Retrieved from https://electronicportfolios.org/digistory/howto.html

Baumann, J. F. (1984). The effectiveness of a direct instruction paradigm for teaching main idea comprehension. Reading Research Quarterly, 20(1), 93-115. https://doi.org/10.2307/747654

Blair, T. R., Rupley, W. H., \& Nichols, W. D. (2007). The effective teacher of reading: Considering the "what" and "how" of instruction. The Reading Teacher, 60(5), 432-438. https://doi.org/10.1598/RT.60.5.3

Carruth, A. K., Pryor, S., Cormier, C., Bateman, A., Matzke, B., \& Gilmore, K. (2010). Evaluation of a school-based train-thetrainer intervention program to teach first aid and risk reduction among high school students. Journal of School Health, 80(9), 453-460. https://doi.org/10.1111/j.1746-1561.2010.00527.x

Clees, T. J., \& Gast, D. L. (1994). Social safety skills instruction for individuals with disabilities: A sequential model. Education veTreatment of Children, 17, 163-185.

Collins, B. C., Wolery, M., \& Gast, D. L. (1991). A survey of safety concerns for students with special needs. Education and Training in Mental Retardation, 26, 305-318.

Dağseven, D. (2001). Zihinsel engelli ögrencilere temel toplama ve saat okuma becerilerinin kazandirlmast, sürekliliği ve genellenebilirliğinde, doğrudan ve basamaklandırılmış öğretim yaklaşımlarına göre hazırlanan ögretim materyalinin farklılaşan etkililiği (Yayınlanmamış Yüksek Lisans Tezi). Gazi Üniversitesi Eğitim Bilimleri Enstitüsü, Ankara.

Dağseven-Emecen, D. (2008). Zihinsel yetersizlikten etkilenmiş öğrencilere sosyal becerilerin kazandırllmasında doğrudan ögrretim ve bilişsel süreç yaklaşımları ile yapılan ögretimin etkililiklerinin ve verimliliklerinin karşılaşstırılması (Yayımlanmamış Doktora Tezi). Gazi Üniversitesi Eğitim Bilimleri Enstitüsü, Ankara.

Dixon, D., Bergstorm, R., Smith, M. N., \& Tarbox, J. (2010). A review of research on procedures for teaching safety skills to persons with developmental disabilities. Research in Developmental Disabilities, 31(5), 985-994. https://doi.org/10.1016/j.ridd.2010.03.007

Erbaş, D. (2012). Güvenirlik [Reliability]. In E. Tekin-İftar (Ed.), Eğitim ve Davranış Bilimlerinde Tek Denekli Araştırmalar (pp. 109-131). Ankara: Türk Psikologlar Derneği Yayınları

Ergenekon, Y. (2012). Teaching Basic First-Aid Skills against Home Accidents to Children with Autism through Video Modeling. Educational Sciences: Theory and Practice, 12(4), 2759-2766.

Eripek, S. (2005). Zekâ geriliği. Ankara: Kök Yayıncılık, Eylül.

Gast, D. L., Winterling, V., Wolery, M., \& Farmer, J. A. (1992). Teaching first-aid skills to students with moderate handicaps in small group instruction. Education and Treatment of Children, 15(2), 101-124. 
Gersten, R. (1985). Direct instruction with special education students: A review of evaluation research. The Journal of Special Education, 19(1), 41-58. https://doi.org/10.1177/002246698501900104

Güzel, R. (1998). Alt özel sinıflardaki ögrrencilerin sesli okudukları öyküyü anlama becerilerini kazanmalarında doğrudan öğretim yöntemiyle sunulan bireyselleştirilmiş okuduğunu anlama materyalinin etkililiği (Yayımlanmamış Doktora Tezi). Gazi Üniversitesi Eğitim Bilimleri Enstitüsü, Ankara.

Güzel, R. (1999). Doğrudan öğretim yönteminin öykü anlama becerisinin öğretiminde uygulanması. Eğitim ve Bilim, 23(111).

Heilman, A. W., Blair, T. R., \& Rupley, W. R. (2002). Principles and practices of teaching reading (10th ed.). Upper Saddle River, NJ: Merrill/Prentice Hall.

Horner, R. H., Carr, E. G., Halle, J., McGee, G., Odom, S., \& Wolery, M. (2005). The use of single-subject research to identify evidence-based practice in special education. Exceptional children, 71(2), 165-179. https://doi.org/10.1177/001440290507100203

Jang, J., Mehta, A., \& Dixon, D. R. (2016). Safety Skills. In N. N. Singh (Ed.), Handbook of Evidence-Based Practices in Intellectual and Developmental Disabilities (pp. 923-941). Springer International Publishing. https://doi.org/10.1007/978-3-319-26583-4_36

Kearney, K. B., Brady, M. P., Hall, K., \& Honsberger, T. (2018). Using peer-mediated literacy-based behavioral interventions to increase first aid safety skills in students with developmental disabilities. Behavior modification, 42(5), 639-660. https://doi.org/10.1177/0145445517725866

Kratochwill, T. R., Hitchcock, J. H., Horner, R. H., Levin, J. R., Odom, S. L., Rindskopf, D. M., \& Shadish, W. R. (2013). Single-case intervention research design standards. Remedial and Special Education, 34(1), 26-38. https://doi.org/10.1177/0741932512452794

Kurt, O. (2012). Sosyal Geçerlik. In E. Tekin-İftar (Ed.), Eğitim ve Davranış Bilimlerinde Tek Denekli Araştırmalar (p. 379). Ankara: Türk Psikologlar Derneği Yayınları.

Liem, G. A. D., \& Martin, A. J. (2013). Direct instruction. International guide to student achievement, 366-368.

Marchand-Martella, N. E., \& Martella, R. C. (1990). The acquisition, maintenance, and generalization of first-aid skills by youths with handicaps. Behavioral Interventions, 5(4), 221-237. https://doi.org/10.1002/bin.2360050402

Marchand-Martella, N. E., Martella, R. C., Agran, M., \& Young, K. R. (1992). Assessing the acquisition of first-aid treatments by elementary-aged children. Child \& family behavior therapy, 13(4), 29-43. https://doi.org/10.1300/J019v13n04_02

Marchand-Martella, N. E., Martella, R. C., Christensen, A. M., Agran, M., \& Young, K. R. (1992). Teaching a first aid skill to students with disabilities using two training programs. Education and treatment of children, 15-31.

Marchand-Martella, N. E., Martella, R. C., Christensen, A. M., Agran, M., \& Young, K. R. (1993). Assessing the duration of first-aid treatments by elementary-aged students with disabilities. Child \& family behavior therapy, 14(3), 33-52. https://doi.org/10.1300/J019v14n03_03

Mechling, L. C. (2008). Thirty year review of safety skill instruction for persons with intellectual disabilities. Education and Training in Developmental Disabilities, 311-323.

Milli Eğitim Bakanlığı (MEB). (2017a). Özel Eğitim Meslek Okulu Akademik Programı, Sosyal Hayat Dersi. Retrieved from http://orgm.meb.gov.tr/meb_iys_dosyalar/2017_09/29160035_Y_Okulu_ProgramY.rar

Milli Eğitim Bakanlığı (MEB). (2017b). Özel Eğitim Uygulama Okulu Programı, Trafik ve İlk Yardım Dersi. Retrieved from http://orgm.meb.gov.tr/meb_iys_dosyalar/2017_09/29160943_EYitim_Uygulama_ Program.rar

Miltenberger, R. G., \& Gross A. C. (2011). Teaching safety skills to children. In W. W. Fisher, C. C. Piazza, \& H. S. Roane (Eds.), Handbook of applied behaviour analysis (pp. 417-430). NY: The Guildfor Press.

Miltenberger, R. G., Sanches, S., \& Valbuena, D. A. (2015). In H. S. Roane, J. E. Ringdahl, \& T. S. Falcomata (Eds.), Clinical and organizational applications of applied behavior analysis (pp. 477-499). Academic Press.

Morgan, H. (2014). Using digital story projects to help students improve in reading and writing. Reading Improvement, 51(1), 20-26 
Nayir, T., Uskun, E., Türkoğlu, H., Uzun, E., Öztürk, M., \& Kişioğlu, N. (2012). Isparta İl Merkezinde Görevli Öğretmenlerin İlkyardım Bilgi Düzeyleri Ve Tutumları. SDÜ Tlp Fakültesi Dergisi, 18(4), 123-127. Retrieved from http://dergipark.gov.tr/sdutfd/issue/21006/225929

Robin, B. (2006). The educational uses of digital storytelling. In C. Crawford (Ed.), Proceedings of Society for Information Technology \& Teacher Education International Conference (2006, pp. 709-716). Chesapeake, VA: AACE.

Sazak, E., \& Merdan, F. (2016). Grafik Düzenleyicilerin Otizmli Öğrencilere Fen Bilgisi Kavramlarının Öğretimindeki Etkililiği. Journal of Kirsehir Education Faculty, 17(1).

Schug, M. C., Tarver, S. G., \& Western, R. D. (2001). Direct Instruction and the Teaching of Early Reading: Wisconsin's Teacher-Led Insurgency. Wisconsin Policy Research Institute Report (Volume 14, Number 2).

Spooner, F., Stem, B., \& Test, D. W. (1989). Teaching first aid skills to adolescents who are moderately mentally handicapped. Education and Training in Mental Retardation, 341-351.

Sümer, S., \& Eldeniz-Çetin, M. (2018). Zihinsel yetersizliği olan bireylerin dinlediklerini anlama düzeyleri üzerinde geleneksel hikaye okuma ve dijital hikaye kullanımının etkililik ve verimliliklerinin karşılaştırılması. Education Sciences, 13(1), 44-55. https://doi.org/10.12739/NWSA.2018.13.1.1C0679

Tekin-İftar, E., (2012). Tek denekli araştırmalar ve temel kavramlar. In E. Tekin-İftar (Ed.), Eğitim ve Davranış Bilimlerinde Tek Denekli Araştırmalar (pp. 15-16). Ankara: Türk Psikologlar Derneği Yayınları.

Timko, T. C., \& Sainato, D. M. (1999). Effects of first aid training using small group instruction with young children with disabilities. Journal of Early Intervention, 22(4), 323-336. https://doi.org/10.1177/105381519902200407

Traub, J. (1999). Better by design? A consumer's guide to schoolwide reform. Washington, DC: Thomas B. Fordham Foundation. Retrieved from https://files.eric.ed.gov/fulltext/ED437423.pdf

Türk Kızılay. (2016). Illk yardım animasyonları. Retrieved from http://www.ilkyardim.org.tr/ilk-yardimanimasyonlari.html

Varol, N. (2014). Zihinsel engelli çocuklara tane kavramının açık anlatım ve basamaklandırılmış yöntemle sunulmasının farklılaşan etkililiği. Gazi Üniversitesi Gazi Eğitim Fakültesi Dergisi, 29(2), 353-377.

Volkmar, F. R., \& Wiesner, L. A. (2009. A practical guide to autism: What every parent, family member, and teacher needs to know (pp. 369-383). New Jersey: John Wiley.

Wang, S., \& Zhan, H. (2010). Enhancing teaching and learning with digital storytelling. International Journal of Information and Communication Technology Education (IJICTE), 6(2), 76-87. https://doi.org/10.4018/jicte.2010040107

Wolf, M. M. (1978). Social Validity: The Case for Subjective Measurement or How Applied Behavior Analysis Is Finding Its Heart 1. Journal of applied behavior analysis, 11(2), 203-214. https://doi.org/10.1901/jaba.1978.11-203

Yamaç, A. (2015). İlkokul üçüncü slnı öğrencilerinin yazma becerilerinin gelişiminde dijital hikâyelerin etkisi (Yayımlanmamış Doktora Tezi). Gazi Üniversitesi Eğitim Bilimleri Enstitüsü, Ankara.

Yang, Y. T. C., \& Wu, W. C. I. (2012). Digital storytelling for enhancing student academic achievement, critical thinking, and learning motivation: A year-long experimental study. Computers \& education, 59(2), 339-352. https://doi.org/10.1016/j.compedu.2011.12.012

Zager, D., \& Shamow, N. (2005). Teaching students with autism spectrum disorder. In D. Zager (Ed.), Autism spectrum disorders (pp. 295-327). Mahwah, NJ: Lawrence Erlbaum Associates.

\section{Copyrights}

Copyright for this article is retained by the author(s), with first publication rights granted to the journal.

This is an open-access article distributed under the terms and conditions of the Creative Commons Attribution license (http://creativecommons.org/licenses/by/4.0/). 